\title{
A Review of Transcranial Magnetic Stimulation in Vascular Dementia
}

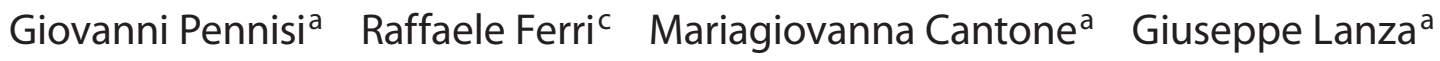 \\ Manuela Pennisi $^{b}$ Luisa Vinciguerra ${ }^{a}$ Giulia Malaguarnera ${ }^{a}$ Rita Bella ${ }^{a}$ \\ Departments of a Neuroscience and ${ }^{\mathrm{b} C h e m i s t r y, ~ U n i v e r s i t y ~ o f ~ C a t a n i a, ~ C a t a n i a, ~ a n d ~}{ }^{\mathrm{c}}$ Department of Neurology I.C., \\ Oasi Institute for Research on Mental Retardation and Brain Aging (IRCCS), Troina, Italy
}

\section{Key Words}

Transcranial magnetic stimulation • Vascular dementia

\begin{abstract}
Vascular dementia (VaD) is a clinical syndrome that encompasses a wide spectrum of cognitive disorders caused by cerebrovascular disease. The subcortical ischemic form of $\mathrm{VaD}$ is clinically homogeneous and a major cause of cognitive impairment in the elderly. Vascular lesions contribute to cognitive decline in neurodegenerative dementias, and $\mathrm{VaD}$ and Alzheimer's disease often coexist and share clinical features and multiple neurotransmission involvement. These similarities have led several investigators to use transcranial magnetic stimulation (TMS) to enucleate a neurophysiological profile of VaD. TMS studies have identified a pattern of cortical hyperexcitability probably related to the disruption of the integrity of white matter lesions due to cerebrovascular disease. The present review provides a perspective of these TMS techniques by further understanding the role of different neurotransmission pathways and plastic remodeling of neuronal networks in the pathogenesis of $\mathrm{VaD}$.
\end{abstract}

Copyright $\odot 2011$ S. Karger AG, Basel
(C) 2011 S. Karger AG, Basel

$1420-8008 / 11 / 0311-0071 \$ 38.00 / 0$

Accessible online at:

www.karger.com/dem

\section{Vascular Dementia and Transcranial Magnetic Stimulation: An Overview}

Vascular dementia $(\mathrm{VaD})$ is considered to be the second most common form of dementia, after Alzheimer's disease (AD) with a prevalence in European studies of $2.6 \%$ in subjects $>65$ years $[1,2]$. However, vascular cognitive impairment, which encompasses any degree of cognitive impairment ranging from an impairment of a specialized cognitive function to $\mathrm{VaD}$ [3-5], is deemed to be the most common type of cognitive disorder [6], affecting approximately $5 \%$ of the people over the age of 65 years [7].

The traditional concept of the multi-infarct dementia model has been revised and now there is agreement that $\mathrm{VaD}$ results from different vascular pathologies, such as subcortical ischemic small-vessel disease as well as cortical infarcts, ischemic-hypoperfusive or hemorrhagic lesions that can lead to numerous clinical phenotypes [8]. This clinical and pathological heterogeneity has caused difficulties and controversies in the diagnosis and classification of $\mathrm{VaD}$ [9-11].

Moreover, cerebrovascular disease (CVD), including small-vessel disease and white matter lesions, is frequently observed in $\mathrm{AD}$ patients, suggesting an overlap be- 
tween $\mathrm{VaD}$ and $\mathrm{AD}$ [12-14]. Vascular amyloid angiopathy is reported in almost all cases of AD. The risk factors for CVD, such as hypertension, atrial fibrillation, diabetes, hypercholesterolemia, atherosclerosis and apolipoprotein $\mathrm{E} \varepsilon 4$ allele, have been shown to increase the risk of AD [15-21]. The deficit in cholinergic neuronal markers and decreased serotonin metabolism observed in $\mathrm{AD}$ have been shown to be associated with $\mathrm{VaD}$ too $[22,23]$. However, $\mathrm{VaD}$ and $\mathrm{AD}$ can be distinguished clinically by the mode of onset and progression of the cortical deficits. Whereas memory and language deficits prevail in $\mathrm{AD}$, executive function is more affected in $\mathrm{VaD}$, possibly due to the interruption of frontal networks [24]. Changes in mood and personality occur earlier and are more severe in $\mathrm{VaD}$ than in $\mathrm{AD}[25,26]$.

The subcortical ischemic vascular dementia (SIVD), due to small-artery disease and hypoperfusion, identifies a clinically homogeneous group of patients and is a major cause of vascular cognitive impairment and dementia [5, 8]. Data from the Leukoaraiosis and Disability (LADIS) study [27] suggested that subcortical ischemic vascular disease is related to progressive cognitive impairment and a considerable risk of developing dementia [28], it is an independent determinant of global functional decline [29], predicts the development of depressive symptoms [30] and is associated with gait and balance disorders [31] or urinary complaints [32] in older people.

Cognitive alterations in $\mathrm{VaD}$, and particularly in SIVD, were suggested to be the consequence of the disruption of the frontal-subcortical circuits that underlie social behavior, and cognitive and executive cortical functions. Lacunes involving the striatum, globus pallidus or thalamus, and periventricular or deep white matter lesions could cause disruption of the prefrontal-subcortical loop, resulting in a variety of neuropsychiatric symptoms. Interruption of the dorsolateral prefrontalsubcortical circuit leads to executive dysfunction; lesions in the orbitofrontal-subcortical loop result in uninhibited behaviors, personality change and emotional lability, whereas decreased motivation, apathy, abulia and even akinetic mutism are caused by lesions in the anterior cingulate circuit [33].

Information processing in the frontal-subcortical circuits is mediated by different neurotransmission pathways. Dopaminergic transmission, through D1 and D2 receptors, mediates a range of frontal executive cognitive functions, such as working memory, attention processes, response inhibition and motor performance. Moreover, through nigral connections with the limbic system mediated by $\mathrm{D} 3$ and $\mathrm{D} 4$ receptors, dopamine is involved in the emotional input and motivation of motor activity [34]. Also, there is a connection between the dopaminergic and cholinergic systems because acetylcholine enhances dopamine release, whereas dopamine modulates cholinergic interneuron activity depending on DA subtype receptors [35]. Moreover, serotonin receptors, present at the level of frontal-subcortical circuits, contribute to the modulation of the dopaminergic pathway [36], suggesting a role for serotonin in mood and behavioral regulation. Glutamate and GABA are also involved in this neurotransmission loop because glutamate stimulates the release of striatal dopamine [37] and basal acetylcholine and GABA is the main neurotransmitter within the basal ganglia [38]. The interaction between dopamine, glutamate, acetylcholine and GABA underlies the corticostriatal-thalamocortical negative feedback loop in order to limit cortical overstimulation.

White matter lesions may directly affect cholinergic projection $[39,40]$, and preclinical $[41,42]$ and clinical evidence $[23,43]$ suggest that the cholinergic system might also be involved in $\mathrm{VaD}$. Moreover, a severe cholinergic deficit in frontal and temporal cortices has been shown to occur in CADASIL cases [44, 45]. Cognitive decline, associated with subcortical CVD, might be the result of hippocampal and cortical atrophy and, although the cause of diffuse cortical atrophy is not known, it may correlate partially with the severity of white matter lesions [46].

In the last years, the identification of an overlap between $\mathrm{VaD}$ and $\mathrm{AD}$ and the involvement of multiple neurotransmission systems have led several investigators to use transcranial magnetic stimulation (TMS) in order to define the neurophysiological profile of $\mathrm{VaD}$ and to help the differential diagnosis between the 2 forms of dementia. TMS is a noninvasive neurophysiological method specifically able to evaluate the primary motor cortex and the corticospinal tract. TMS was developed as a useful method in order to explore the development of the corticospinal system, the functioning of the healthy brain and to evaluate the involvement of the corticopiramidal tract in a variety of neurological diseases. Many TMS studies have examined motor cortex excitability and motor cortical output after acute stroke, in the poststroke recovery and in brain reorganization, providing relevant data for their prognosis and therapeutic approach [47-53]. TMS has also been applied to study motor cortex changes in patients with cognitive disorders such as AD [54-59], frontotemporal dementia [59] and dementia with Lewy bodies [60].

Various measures of motor cortex excitability and inhibition in normal and pathological conditions have been 
Table 1. Selected peer-reviewed articles on cortical excitability to TMS in VaD

\begin{tabular}{|c|c|c|c|c|c|c|c|c|c|c|}
\hline \multicolumn{2}{|l|}{ Studies } & \multicolumn{2}{|c|}{$\begin{array}{l}\text { Demographic and } \\
\text { clinical characteristics }\end{array}$} & \multicolumn{7}{|c|}{ TMS parameters } \\
\hline authors & study design & $\begin{array}{l}\text { mean } \\
\text { age } \\
\text { years }\end{array}$ & $\begin{array}{l}\text { VaD } \\
\text { subtype }\end{array}$ & type of coil & $\begin{array}{l}\text { mean } \\
\text { rMT } \\
\%\end{array}$ & $\begin{array}{l}\text { mean } \\
\text { aMT } \\
\%\end{array}$ & $\begin{array}{l}\text { CSP } \\
\text { ms }\end{array}$ & $\begin{array}{l}\text { ICI } \\
\%\end{array}$ & $\begin{array}{l}\text { ICF } \\
\%\end{array}$ & $\begin{array}{l}\text { SAI } \\
\%\end{array}$ \\
\hline Alagona et al. [73] & 20 SIVD, 20 AD, 20 controls & $71.8 \pm 9.4$ & SIVD & circular & $32.7 \pm 2.6^{* *}$ & & n.s. & & & \\
\hline Di Lazzaro et al. [82] & 12 SIVD, 12 AD, 12 controls & $70.9 \pm 9.6$ & SIVD & figure of eight & $\mathrm{R} 48.8 \pm 8.1^{*}$ & n.s. & & n.s. & & n.s. \\
\hline Nardone et al. [83] & 20 SIVD, 20 controls & $70.9 \pm 4.4$ & SIVD & figure of eight & n.s. & n.s. & n.s. & n.s. & n.s. & $73.5 \pm 13.4^{*}$ \\
\hline Manganelli et al. [84] & 10 CADASIL, 10 controls & $61.4 \pm 8.5$ & CADASIL & figure of eight & $\mathrm{R} 49.4 \pm 14.4^{*}$ & & & & & $79.5 \pm 21.7^{*}$ \\
\hline Pennisi et al. [85] & 20 SIVD, 20 SIDWD, 20 controls & $71.8 \pm 9.4$ & SIVD & circular & $32.7 \pm 2.6^{* *}$ & & n.s. & & & \\
\hline
\end{tabular}

evaluated by different TMS techniques. Using singlepulse TMS, motor threshold (MT) at rest or during active movements can be measured. MT is the expression of the level of neuronal membrane excitability because it can be modulated by drugs that block voltage-gated sodium channels [61]. It may reflect the local density of a central core of excitatory interneurons and of corticospinal neurons within the human motor cortex. The interval of suppression of the voluntary electromyographic activity following a single-pulse TMS stimulus, the so-called cortical silent period (CSP), is indeed a measure of motor cortical inhibition and it is due largely to the activation of cortical inhibitory interneurons mediated by GABA-B receptors [62].

Using the paired-pulse paradigm, TMS has revealed the existence of a complex intracortical phenomenon within the human brain by means of the study of shortlatency intracortical inhibition (SICI) and intracortical facilitation (ICF) [63]. SICI and ICF are considered to be mediated by different neural circuits: SICI is probably mediated by GABA-A receptors [64], whereas the phenomenon of facilitation seems to origin from intracortical glutamatergic neurons, since dextromethorphan, an $\mathrm{N}$-methyl-D-aspartate (NMDA) receptor antagonist, reduces the ICF [65]. Nevertheless, the interpretation of the ICF seems to be more difficult [66].

Using a different TMS paradigm it is possible to investigate the sensory-motor interaction within the cerebral cortex and the cortical phenomenon of the short afferent inhibition (SAI) [67]. SAI seems to be related to a central cholinergic inhibitory circuit because scopolamine causes its reduction in healthy subjects [68]. SAI might also be connected to GABAergic circuits [69] and could be influenced by other neurotransmitters such as glutamate or dopamine [57]. SAI is reduced in some con- ditions characterized by an impairment of memory, such as $\mathrm{AD}[56]$ and other dementing disorders.

Single TMS pulses delivered in trains are the principle of the repetitive TMS (rTMS), an approach that can transiently influence the function of stimulated brain areas, mainly depending on the frequency of stimulation. rTMS might also have therapeutic and rehabilitative applications since the effects of repeated sessions may persist in time. rTMS as a therapeutic approach is widely suggested in psychiatric disorders [70,71]. The mechanisms of these changes are not clear, but they seem to be related to synaptic long-term potentiation and long-term depression [72].

\section{Cortical Excitability in VaD}

TMS has been used to study the motor cortex in patients with vascular cognitive disorders. However, so far we have identified only 5 published reports in the literature on TMS studies in VaD (table 1) and 1 rTMS study in SIVD with executive dysfunction. Currently, these few studies on patients with vascular dementia provide additional information on the underlying mechanism of cognitive complications in CVD.

In 2004, Alagona et al. [73] studied 20 SIVD patients, diagnosed according to the criteria proposed by Erkinjuntti in 2002 [74], $20 \mathrm{AD}$ patients and 20 control subjects. They used the single-pulse TMS technique to evaluate cortical excitability through the assessment of the resting MT (rMT), according to recommended criteria for its estimation [75]. These authors found a reduced rMT in both patient groups with respect to controls. Moreover, SIVD patients showed lower values than AD patients. No statistically significant difference was found in the $\mathrm{H} / \mathrm{M}$ am- 
plitude ratio between patients and controls, thus the hyperexcitability was not due to increased spinal motor neuron excitability. Furthermore, the CSP was not different in the 2 groups of patients.

This study showed an enhanced motor cortex excitability in SIVD subjects, similar to that of AD patients. The authors hypothesized that the hyperexcitability could be associated with the neurodegeneration mediated by an abnormal glutamate mechanism. In fact, vascular cognitive disorders are the result of ischemic insults that probably trigger the different mechanisms of neurodegeneration also in this form of dementia [76].

Excitotoxicity is a major cause of neuronal loss after hypoxic-ischemic damage [77]. Glutamate is responsible for synaptic transmission through the activation of ionotropic glutamate receptors sensitive to NMDA, AMPA ( $\alpha$-amino-3-hydroxy-5-methyl-4-isoxazolepropionic acid) or kainate. This glutamatergic mechanism underlies neuronal plasticity and normal information processing [78]. The energy deficit following cerebral ischemia increases the release of glutamate by presynaptic membrane depolarization, with a subsequent synaptic activation of voltage-gated $\mathrm{Ca}^{2+}$ channels. Moreover, it inhibits the glutamate reuptake by astrocytes and causes an additional accumulation of glutamate in the synaptic space. Excessive activation of ionotropic glutamate receptors leads to neuronal death following the intraneural overload of $\mathrm{Ca}^{2+}$ and the subsequent activation of the $\mathrm{Ca}^{2+}$ dependent proteins (calpain, cytoplasmic phospholipase $\mathrm{A} 2$, protein kinase $\mathrm{Ca}^{2+}$-dependent, endonuclease). The accumulation of $\mathrm{Ca}^{2+}$ also leads to the production of free radicals through the activation of pro-oxidant processes [79]. Thus, neuronal death occurs through multiple mechanisms causing apoptosis [80].

Moreover, the dysregulation of the delicate balance between excitatory and inhibitory mechanisms may be the cause of the cortical excitability abnormalities. The damage to the cholinergic system may contribute to the cognitive decline of patients with $\mathrm{VaD}$, similarly to $\mathrm{AD}$ patients. Therefore, this study suggested that an impaired cholinergic transmission might be a pathologic mechanism leading to the increment of motor cortex excitability in $\mathrm{VaD}$ patients, as it occurs in $\mathrm{AD}[56,81]$.

In 2008, Di Lazzaro et al. [82] studied $12 \mathrm{VaD}$ patients with neuroradiological evidence of small-vessel disease, $12 \mathrm{AD}$ patients and 12 age-matched healthy subjects. There was a significant reduction of $\mathrm{rMT}$ in $\mathrm{VaD}$ and $\mathrm{AD}$ patients with respect to controls, but there were no significant differences between the $\mathrm{VaD}$ and $\mathrm{AD}$ groups. In agreement with the previous study, patients with $\mathrm{VaD}$ ex- hibited increased cortical excitability that might be interpreted to be a functional consequence of subcortical CVD. Moreover, SICI was reduced in a small group of $\mathrm{VaD}$ patients, suggesting a possible role for GABAergic circuits in the genesis of hyperexcitability in the motor cortex. Additionally, SAI was found to be decreased in $\mathrm{AD}$ patients, while it was normal in most $\mathrm{VaD}$ patients, making the cholinergic hypothesis unlikely in this form of dementia. Indeed, SAI was significantly decreased only in $25 \%$ of the patients with $\mathrm{VaD}$, suggesting a mixed form of dementia and a possible role for a cholinergic system impairment in this group of patients. SAI was strongly correlated with neuropsychological measures of longterm memory and other higher cortical functions, suggesting a central role for acetylcholine in the memory processes.

Nardone et al., in a different study design [83] including 20 SIVD patients and 20 controls, did not confirm the results of the previous reports. There were no differences between the 2 groups for the neurophysiological parameters measured (central motor conduction time, CSP, SICI, ICF) and, in particular, for MT. The reason of this difference is not clear, even if the inclusion criteria, age and tools were similar. SAI was significantly lower in SIVD patients than in the healthy group. There were no correlations between SAI and neuropsychological results, neuroradiological features, patient age or disease duration. The authors proposed that there was a central cholinergic circuit impairment in this pathology, as in $\mathrm{AD}$ [56] and in CADASIL [84]. Therefore, they suggested that the use of cholinomimetics drugs, such as acetylcholinesterase, could be helpful to improve cognitive impairment and cerebral blood flow in VaD subjects. SAI might be a valid tool to evaluate the effects of drugs on the cholinergic system and to predict the clinical response to treatment in these patients.

In a recent study, Pennisi et al. [85] demonstrated that in the subcortical ischemic disease, motor cortex hyperexcitability was a peculiar finding only in patients with dementia. These authors studied 20 SIVD and 20 subcortical ischemic disease without dementia patients (SIDWD) and 20 healthy subjects. rMT was lower in SIVD patients than in SIDWD patients and in healthy subjects. The study confirmed that the enhanced motor cortex excitability is not merely related to cerebrovascular lesions. Despite the cognitive impairment observed in these patients being the result of damage in frontal-subcortical circuits caused by strategic infarcts, CVD itself cannot justify the observed hyperexcitability of the motor cortex. In fact, previous studies showed that strategic 
lacunar infarcts in the pyramidal tract often reduce corticospinal excitability, despite the complete motor recovery [50]. Moreover, it has been reported that chronic cerebrovascular lesions usually do not influence motor cortex excitability [86].

No correlation was found between changes of cortical excitability and neuroimaging data. This can probably be due to the fact that studies have evaluated vascular lesions using simple visual scales that do not allow a precise quantification of the vascular damage. Moreover, as shown by recent imaging studies [87], invisible white matter damage may contribute to the development of vascular cognitive disorders. Thus, further studies should be performed to address also this matter.

\section{TMS Studies in CADASIL}

The cerebral autosomal dominant arteriopathy with subcortical infarcts and leukoencephalopathy (CADASIL) is perhaps the typical hereditary CVD. CADASIL is due to mutations in the Notch3 gene on chromosome 19 and causes progressive cognitive decline until dementia, cerebral ischemic events, psychiatric disorders and migraine with aura. It is a small-vessel disease and represents a pure vascular dementia model; for this reason, patients with CADASIL are particularly suitable for studying the relationship between ischemic brain injury and clinical manifestations.

Neuropathological data in a postmortem single case of CADASIL [44] and immunocytochemical studies [45] showed cholinergic neuronal denervation, anomalies in cholinergic neuronal activities and interruption of axonal projections along the white matter tracts to the frontal cortex.

In 2008, Manganelli et al. [84] first demonstrated with an 'in vivo' electrophysiological study a dysfunction of motor cortex cholinergic innervations, utilizing SAI measurement. In CADASIL patients, rMT and SAI were significantly lower than in healthy individuals, while SAI was normal in the only patient that showed a normal neuropsychological evaluation. These results support the hypothesis of a central cholinergic system impairment in CADASIL $[44,45]$. The recurrent vascular insults and the lesional burden in strategic areas $[39,40]$, such as the external capsule, typically involved in CADASIL [88, 89], lead to the interruption of cortico-subcortical cholinergic circuits $[39,90]$. rMT was reduced in CADASIL patients and this cortical hyperexcitabilty can be caused by cholinergic, GABA and glutamate neurons. The cholinergic system may influence GABA and glutamate circuits, thus CADASIL might involve several neurotransmitter systems, similarly to AD.

\section{TMS Studies in Alzheimer's Disease}

In the last years, many TMS studies were carried out in $\mathrm{AD}$ patients with the aim of understanding the changes in motor cortex excitability. Most studies reported that rMT is generally reduced in $\mathrm{AD}$, and this result is interpreted as a marker of increased motor cortex excitability [54-57, 73, 82, 85, 91-93]. Using paired-pulse TMS, some, but not all, studies showed that ICI is reduced in AD patients $[59,94,95]$, whereas no changes are observed in ICF [56, 59, 83, 94-96], suggesting a possible involvement of intracortical GABAergic circuits. Finally, an impairment of the central cholinergic transmission is clearly demonstrated in $\mathrm{AD}[56,57,82,97,98]$. At present, however, it is not clear if the hyperexcitability of the motor cortex in $\mathrm{AD}$ is the expression of a selective involvement of excitatory glutamatergic circuits or an impairment of inhibitory cholinergic and, to a lesser extent, GABAergic activity. Although the cholinergic deficit seems to be the most accepted hypothesis, recent results indicate that $\mathrm{AD}$ should be considered as a complex neurodegenerative disease, involving different neurotransmitter systems.

\section{Discussion}

The reduction of $\mathrm{rMT}$ in $\mathrm{VaD}$ is a relatively constant result, suggesting a pattern of global increased cortical excitability $[73,82,85]$, as already reported in AD. The neurophysiological similarity between $\mathrm{VaD}$ and $\mathrm{AD}$ at TMS evaluation supports the hypothesis that the 2 disorders often coexist as mixed-type dementia.

Cortical hyperexcitabilty evaluated by TMS can be due to an imbalance of excitatory and inhibitory circuits within the cerebral cortex, leading to a disinhibition of the motor cortex itself. Since the principal excitatory neurotransmitter is glutamate, the glutamatergic system could have a relevant role in the hyperexcitability of the motor areas. In particular, there can be a disproportion between non-NMDA and NMDA neurotransmission in favor of the non-NMDA system [57]. Thus, in VaD patients hyperexcitabilty could be due to an altered glutamatergic neurotransmission, as observed after stroke [99]. 
On the other hand, Di Lazzaro et al. [82] found an impairment of SICI in $16 \%$ of their patients, possibly due to an involvement of GABAergic intracortical inhibitory mechanisms.

In fact, Ihara et al. [100] recently affirmed that in leukoaraiosis patients with dementia a bilateral reduction of cortical benzodiazepine receptors exists in the frontopolar and frontal-insular areas, the left temporo-occipital border areas and the left marginal cortical areas, caused by different ischemic lesions in white matter and by disruption of cortical-subcortical circuits.

The impairment of intracortical inhibitory circuits can be linked to GABA-A activity or to inhibitory cholinergic mechanisms. For instance, the blockade of cholinergic muscarinic receptors with scopolamine causes an enhanced cortical excitability measured by TMS [68]. In any case, one possible mechanism is that the reduced corticospinal output activates to a lesser extent recurrent axon collaterals and consequently conducts to a reduced inhibitory effect on corticospinal neurons [101].

The role of the cholinergic system in the development of cognitive impairment is still under discussion also because there are conflicting results on the role of cholinergic circuit activity evaluated by afferent inhibition. $\mathrm{Di}$ Lazzaro et al. [82] affirm that in VaD subjects there is no alteration of the central cholinergic circuits. On the other hand, Manganelli et al. [84] and Nardone et al. [83] suggest that the cholinergic neurotransmission can play a role in the cognitive decline of CADASIL and SIVD patients, respectively.

Despite its high sensitivity in evaluating the global weight of several neurotransmitters in VaD, TMS does not provide data about a specific neurotransmission activity [102].

Probably hyperexcitability may be related to the disruption of the integrity of cerebral white matter due to CVD that could damage axons travelling within the white matter, resulting in degeneration of neurons in the subcortical and cortical gray matter.

It is important to note that a diffusion-weighted imaging study conducted in elderly subjects enrolled in the LADIS study showed a significant correlation between ultrastructural abnormalities of the normal-appearing brain tissue and cognition impairment. This suggests that both visible and invisible microstructural white matter alterations are key factors in the evolution of the cognitive impairment [87].

The hypothesis that the described alterations of motor cortex excitability could be related to aging is unlikely. First, in all studies, a control group matched for age has always been included. Secondly, several studies have described the effect of aging on motor cortex circuits reporting results opposite to those found in studies on $\mathrm{VaD}$. An age-related reduction of MEP amplitude has been reported in controls [103], whereas in patients with $\mathrm{VaD}$ Alagona et al. found a small (not statistically significant) increase in MEPs size [73].

A significant increase in MT was found in healthy subjects with aging [104], while in patients with $\mathrm{VaD}$, the majority of studies argues that there is a reduction of MT. However Silbert et al. [105] found that white matter hyperintensity volume is associated with decreased rMT.

Aging is also associated with a relative decrease in the excitability of some cortical inhibitory circuits. Shortening of CSP [103] and a reduction of SICI [106] were reported with aging, but these findings were not reported in $\mathrm{VaD}$ patients. Finally, no significant effect of aging was found for SAI [103].

The hyperexcitability of motor cortex might be the result of a functional reorganization of cortical areas similar to the compensatory mechanisms that occur in $\mathrm{AD}$ $[96,107]$ and CADASIL patients. In fact, a functional magnetic resonance imaging study of patients with CADASIL showed changes in motor cortex activation in response to the typical subcortical vascular injury. In particular, a greater ipsilateral premotor and primary motor area activation was observed with hand movement that increased with axonal damage. This functional cortical reorganization seems to be an adaptive process to limit motor impairment subsequent to the subcortical injury of CADASIL [108].

To date, the studies on rTMS as a treatment of VaD are scarce and its hypothetical mechanisms are still unclear. The randomized controlled pilot study of Rektorova et al. [109] showed that 1 session of high-frequency rTMS applied over the left dorsolateral prefrontal cortex was able to improve executive functioning, whereas no effects were observed in any other cognitive functions. However, the study was performed on a small group of patients suffering from CVD with mild cognitive impairment but without dementia. Moreover, the efficacy and safety of high-frequency rTMS were tested for the treatment of elderly patients with vascular depression, which is known to be more frequently drug resistant than the early-onset depression [110-112]. A recent study of rTMS in rat models of $\mathrm{VaD}$ has reported an improvement of both learning and memory abilities after the administration of low-frequency or high-frequency stimuli. As suggested by the authors, the restoration of cognitive functions could be the result of the biological effects of rTMS that probably 
acts by promoting the expression of brain-derived neurotrophic factor and other proteins, such as NMDAR1 and synaptophysin, involved in neuronal cell protection, synaptic transmission and brain plasticity [113].

The majority of TMS results indicate that the cortex of $\mathrm{VaD}$ patients is hyperexcitable, a common feature shared also by $\mathrm{AD}$. Literature on TMS in the early stage of $\mathrm{VaD}$ is lacking. The few studies on amnestic MCI-early AD failed to detect significant alterations in cortical motor neuron excitability $[114,115]$. Future studies using TMS together with biomarkers and neuroimaging could be useful in identifying the brain at risk for dementia and in prognosticating disease progression.

In conclusion, although several neuroradiological reports on $\mathrm{VaD}$ have been published, up to now only few neurophysiological studies have examined cortex excitability in patients with cognitive decline following vascular brain damage. All the findings suggest that the use of TMS is already a valuable tool in the study of the neurophysiological basis of cognitive disorders. Further TMS studies are needed to understand the impact of subcortical vascular lesions on cortical excitability and the role of multiple neurotransmitter involvement in $\mathrm{VaD}$ patients.

To date, no studies have been conducted at the predementia stage and correlations between cortical excitability and cognitive performance have not been addressed. Moreover, studies on the impact of drugs on cortex excitability of vascular dementia are scarce. However, studies with rTMS are able to provide data for a rehabilitative application with the aim of improving cognitive performance in $\mathrm{VaD}$.

A PubMed-based literature review of English-language studies was performed to acquire publications on $\mathrm{VaD}$ and TMS. Key search words were vascular dementia, subcortical ischemic vascular dementia, vascular cognitive disorders, vascular cognitive impairment, Alzheimer's disease, neurotransmitters, transcranial magnetic stimulation and motor cortex excitability. We have also reviewed the articles in references to locate data on CVD and TMS.

\section{References}

1 Fratiglioni L, Laurer LJ, Andersen K, Breteler MM, Copeland JR, Dartigues JF, Lobo A, Martinez-Lage J, Soininen H, Hofman A: Incidence of dementia and major subtypes in Europe: a collaborative study of population base cohorts. Neurology 2000;54:S10-S15.

$\checkmark 2$ Lobo A, Launer LJ, Fratiglioni L, Andersen K, Di Carlo A, Breteler MM, Copeland JR, Dartigues JF, Jagger C, Martinez-Lage J, Soininen H, Hofman A, Neurologic Diseases in the Elderly Research Group: Prevalence of dementia and major subtypes in Europe: a collaborative study of population-based cohorts. Neurology 2000;54:S4-S9.

3 Hachinski V: Vascular dementia: a radical redefinition. Dementia 1994;5:130-132.

4 Bowler JV: The concept of vascular cognitive impairment. J Neurol Sci 2002;203-204:1115.

-5 O’Brien JT, Erkinjuntti T, Reisberg B, Roman G, Sawada T, Pantoni L, Bowler JV, Ballard C, DeCarli C, Gorelick PB, Rockwood K, Burns A, Gauthier S, DeKosky ST: Vascular cognitive impairment. Lancet Neurol 2003; 2:89-98.

6 Román GC: Vascular dementia may be the most common form of dementia in the elderly. J Neurol Sci 2002;203-204:7-10.

7 Moorhouse P, Rockwood K: Vascular cognitive impairment: current concepts and clinical developments. Lancet Neurol 2008;7: 246-255.
8 Román GC, Erkinjuntti T, Wallin A, Pantoni L, Chui HC: Subcortical ischaemic vascular dementia. Lancet Neurol 2002;1:426-436.

$\checkmark 9$ Román GC, Tatemichi TK, Erkinjuntti T, Cummings JL, Masdeu JC, Garcia JH, Amaducci L, Orgogozo JM, Brun A, Hoffman A, Moody DM, O'Brien MD, Yamaguchi T, Grafman J, Drayer BP, Bennett DA, Fisher M, Ogata J, Kokmen E, Bermejo F, Wolf PA, Gorelick PB, Bick KL, Pajeau AK, Bell MA, DeCarli C, Culebras A, Korezyn AD, Bogousslavsky J, Hartmann A, Scheimberg P: Vascular dementia: diagnostic criteria for research studies: report of the NINDS-AIREN International Workshop. Neurology 1993; 43:250-260.

10 Chui HC, Victoroff JI, Margolin D, Jagust W, Shankle R, Katzman R: Criteria for the diagnosis of ischemic vascular dementia proposed by the State of California Alzheimer's Disease Diagnostic and Treatment Centers. Neurology 1992;42:473-480.

11 WHO: ICD-10: International Classification of Diseases, ed 10. Geneva, WHO 1992.

12 Snowdon DDA, Greiner LH, Mortimer JA, Riley KP, Greiner PA, Markesbery WR: Brain infarction and the clinical expression of Alzheimer disease: The Nun Study. JAMA 1997;277:813-817.

13 Englund E, Brun A, Persson B: Correlations between histopathologic white matter changes and proton MR relaxation times in dementia. Alzheimer Dis Assoc Disord 1987; 1:156-170.
14 Kalaria R: Similarities between Alzheimer's disease and vascular dementia. J Neurol Sci 2002;203-204:29-34

15 Skoog I, Lernfelt B, Landahl S, Palmertz B, Andreasson LA, Nilsson L, Persson G, Odén A, Svanborg A: 15-year longitudinal study of blood pressure and dementia. Lancet 1996; 347:1141-1145.

16 Ott A, Breteler MM, de Bruyne MC, van Harskamp F, Grobbee DE, Hofman A: Atrial fibrillation and dementia in a populationbased study: The Rotterdam Study. Stroke 1997;28:316-321.

17 Ott A, Stolk RP, van Harskamp F, Pols HA, Hofman A, Breteler MM: Diabetes mellitus and the risk of dementia: The Rotterdam Study. Neurology 1999;53:1937-1942.

18 Jick H, Zornberg GL, Jick SS, Seshadri S, Drachman DA: Statins and the risk of dementia. Lancet 2000;356:1627-1631.

$\checkmark 19$ Roher AE, Esh C, Kokjohn TA, Kalback W, Luehrs DC, Seward JD, Sue LI, Beach TG: Circle of Willis atherosclerosis is a risk factor for sporadic Alzheimer's disease. Arterioscler Thromb Vasc Biol 2003;23:2055-2062.

20 Kalaria RN: Arteriosclerosis, apolipoprotein E, and Alzheimer's disease. Lancet 1997;349: 1174-1175.

21 Premkumar DR, Cohen DL, Hedera P, Friedland RP, Kalaria RN: Apolipoprotein E- $\varepsilon 4$ alleles in cerebral amyloid angiopathy and cerebrovascular pathology associated with Alzheimer's disease. Am J Pathol 1996;148: 2083-2095. 
-22 Perry EK, Gibson PH, Blessed G, Perry RH, Tomlinson BE: Neurotransmitter enzyme abnormalities in senile dementia: choline acetyltransferase and glutamic acid decarboxylase activities in necropsy brain tissue. J Neurol Sci 1977;34:247-265.

$\checkmark 23$ Gottfries CG, Blennow K, Karlsson I, Wallin A: The neurochemistry of vascular dementia. Dementia 1994;5:163-167.

-24 Román GC, Royall DR: Executive control function: a rational basis for the diagnosis of vascular dementia. Alzheimer Dis Assoc Disord 1999;13:S69-S80.

-25 Hargrave R, Geck LC, Reed B, Mungas D: Affective behavioural disturbances in Alzheimer's disease and ischaemic vascular disease. J Neurol Neurosurg Psychiatry 2000; 68:41-46.

26 Groves WC, Brandt J, Steinberg M, Warren A, Rosenblatt A, Baker A, Lyketsos CG: Vascular dementia and Alzheimer's disease: is there a difference? A comparison of symptoms by disease duration. J Neuropsychiatry Clin Neurosci 2000;12:305-315.

-27 Pantoni L, Basile AM, Pracucci G, Asplund K, Bogousslavsky J, Chabriat H, Erkinjuntti T, Fazekas F, Ferro JM, Hennerici M, O’Brien J, Scheltens P, Visser MC, Wahlund LO, Waldemar G, Wallin A, Inzitari D: Impact of age-related cerebral white matter changes on the transition to disability - the LADIS study: rationale, design and methodology. Neuroepidemiology 2005;24:51-62.

-28 Jokinen H, Kalska H, Ylikoski R, Madureira S, Verdelho A, van der Flier WM, Scheltens P, Barkhof F, Visser MC, Fazekas F, Schmidt R, O'Brien J, Waldemar G, Wallin A, Chabriat $\mathrm{H}$, Pantoni L, Inzitari $\mathrm{D}$, Erkinjuntti T; LADIS group: Longitudinal cognitive decline in subcortical ischemic vascular disease - the LADIS Study. Cerebrovasc Dis 2009;27:384-391.

>29 Inzitari D, Pracucci G, Poggesi A, Carlucci G, Barkhof F, Chabriat H, Erkinjuntti T, Fazekas F, Ferro JM, Hennerici M, Langhorne P, O’Brien J, Scheltens P, Visser MC, Wahlund LO, Waldemar G, Wallin A, Pantoni L; LADIS Study Group: Changes in white matter as determinant of global functional decline in older independent outpatients: three-year follow-up of LADIS (leukoaraiosis and disability) study cohort. BMJ 2009;339:b2477.

-30 Teodorczuk A, Firbank MJ, Pantoni L, Poggesi A, Erkinjuntti T, Wallin A, Wahlund LO, Scheltens P, Waldemar G, Schrotter G, Ferro JM, Chabriat H, Bazner H, Visser M, Inzitari D, O'Brien JT; LADIS Group: Relationship between baseline white-matter changes and development of late-life depressive symptoms: 3-year results from the LADIS study. Psychol Med 2010;40:603-610.
Baezner H, Blahak C, Poggesi A, Pantoni L, Inzitari D, Chabriat $\mathrm{H}$, Erkinjuntti $\mathrm{T}$, Fazekas F, Ferro JM, Langhorne P, O’Brien J, Scheltens $\mathrm{P}$, Visser MC, Wahlund LO, Waldemar G, Wallin A, Hennerici MG; LADIS Study Group: Association of gait and balance disorders with age-related white matter changes: the LADIS study. Neurology 2008;70:935-942.

32 Poggesi A, Pracucci G, Chabriat H, Erkinjuntti T, Fazekas F, Verdelho A, Hennerici M, Langhorne P, O’Brien J, Scheltens P, Visser MC, Crisby M, Waldemar G, Wallin A, Inzitari D, Pantoni L; Leukoaraiosis and DISability Study Group: Urinary complaints in nondisabled elderly people with age-related white matter changes: the Leukoaraiosis and DISability (LADIS) Study. J Am Geriatr Soc 2008;56:1638-1643.

33 Cummings JL: Frontal-subcortical circuits and human behavior. Arch Neurol 1993;50: 873-880.

34 Mega MS, Cummings JL: Frontal-subcortical circuits and neuropsychiatric disorders. J Neuropsychiatry Clin Neurosci 1994;6:358370.

35 McGeer PL, McGeer EG: Neurotransmitters and their receptors in the basal ganglia. Adv Neurol 1993;60:93-101.

36 Di Giovanni G, Di Matteo V, Pierucci M, Esposito E: Serotonin-dopamine interaction: electrophysiological evidence. Prog Brain Res 2008;172:45-71.

37 Morari M, Marti M, Sbrenna S, Fuxe K, Bianchi C, Beani L: Reciprocal dopamineglutamate modulation of release in the basal ganglia. Neurochem Int 1998;33:383-397.

38 Tepper JM, Lee CR: GABAergic control of substantia nigra dopaminergic neurons. Prog Brain Res 2007;160:189-208.

39 Selden NR, Gitelman DR, Salamon-Murayama N, Parrish TB, Mesulam MM: Trajectories of cholinergic pathways within the cerebral hemispheres of the human brain. Brain 1998;121:2249-2257.

40 Swartz RH, Sahlas DJ, Black SE: Strategic involvement of cholinergic pathways and executive dysfunction: does location of white matter signal hyperintensities matter? J Stroke Cerebrovasc Dis 2003;12:29-36.

41 Togashi H, Matsumoto M, Yoshioka M, Hirokami M, Minami M, Saito H: Neurochemical profiles in cerebrospinal fluid of strokeprone spontaneously hypertensive rats. Neurosci Lett 1994;166:117-120.

42 Kimura S, Saito H, Minami M, Togashi H, Nakamura N, Nemoto M, Parvez HS: Pathogenesis of vascular dementia in stroke-prone spontaneously hypertensive rats. Toxicology 2000;153:167-178.

-43 Martin-Ruiz C, Court J, Lee M, Piggott M, Johnson M, Ballard C, Kalaria R, Perry R, Perry E: Nicotinic receptors in dementia of Alzheimer, Lewy body and vascular types. Acta Neurol Scand Suppl 2000;176:34-41.
44 Mesulam M, Siddique T, Cohen B: Cholinergic denervation in a pure multi-infarct state: observations on CADASIL. Neurology 2003; 60:1183-1185.

45 Keverne JS, Low WC, Ziabreva I, Court JA, Oakley AE, Kalaria RN: Cholinergic neuronal deficits in CADASIL. Stroke 2007;38: 188-191.

46 Fein G, Di Sclafani V, Tanabe J, Cardenas V, Weiner MW, Jagust WJ, Reed BR, Norman D, Schuff N, Kusdra L, Greenfield T, Chui H: Hippocampal and cortical atrophy predict dementia in subcortical ischemic vascular disease. Neurology 2000;55:1626-1635.

-47 Rapisarda G, Bastings E, de Noordhout AM, Pennisi G, Delwaide PJ: Can motor recovery in stroke patients be predicted by early transcranial magnetic stimulation? Stroke 1996;27:2191-2196.

-48 Traversa R, Cicinelli P, Bassi A, Rossini PM, Bernardi G: Mapping of motor cortical reorganization after stroke: a brain stimulation study with focal magnetic pulses. Stroke 1997;28:110-117.

-49 Alagona G, Delvaux V, Gérard P, De Pasqua V, Pennisi G, Delwaide PJ, Nicoletti F, Maertens de Noordhout A: Ipsilateral motor responses to focal transcranial magnetic stimulation in healthy subjects and acutestroke patients. Stroke 2001;32:1304-1309.

50 Pennisi G, Alagona G, Rapisarda G, Nicoletti F, Costanzo E, Ferri R, Malaguarnera M, Bella R: Transcranial magnetic stimulation after pure motor stroke. Clin Neurophysiol 2002;113:1536-1543.

51 Cicinelli P, Pasqualetti P, Zaccagnini M, Traversa $\mathrm{R}$, Oliveri $\mathrm{M}$, Rossini PM: Interhemispheric asymmetries of motor cortex excitability in the postacute stroke stage: a pairedpulse transcranial magnetic stimulation study. Stroke 2003;34:2653-2658.

52 Profice P, Pilato F, Dileone M, Ranieri F, Capone F, Musumeci G, A Tonali P, Di Lazzaro $\mathrm{V}$ : Use of transcranial magnetic stimulation of the brain in stroke rehabilitation. Expert Rev Neurother 2007;7:249-258.

53 Di Lazzaro V, Profice P, Pilato F, Capone F, Ranieri F, Pasqualetti $\mathrm{P}$, Colosimo C, Pravatà E, Cianfoni A, Dileone M: Motor cortex plasticity predicts recovery in acute stroke. Cereb Cortex 2010;20:1523-1528.

54 Alagona G, Bella R, Ferri R, Carnemolla A, Pappalardo A, Costanzo E, Pennisi G: Transcranial magnetic stimulation in Alzheimer disease: motor cortex excitability and cognitive severity. Neurosci Lett 2001;314:57-60.

55 Pennisi G, Alagona G, Ferri R, Greco S, Santonocito D, Pappalardo A, Bella R: Motor cortex excitability in Alzheimer disease: one-year follow-up study. Neurosci Lett 2002;329:293-296. 
56 Di Lazzaro V, Oliviero A, Tonali PA, Marra C, Daniele A, Profice P, Saturno E, Pilato F, Masullo C, Rothwell JC: Noninvasive in vivo assessment of cholinergic cortical circuits in $\mathrm{AD}$ using transcranial magnetic stimulation. Neurology 2002;59:392-397.

-57 Di Lazzaro V, Oliviero A, Pilato F, Saturno E, Dileone M, Marra C, Daniele A, Ghirlanda S, Gainotti G, Tonali PA: Motor cortex hyperexcitability to transcranial magnetic stimulation in Alzheimer's disease. J Neurol Neurosurg Psychiatry 2004;75:555-559.

58 Inghilleri M, Conte A, Frasca V, Scaldaferri N, Gilio F, Santini M, Fabbrini G, Prencipe $\mathrm{M}$, Berardelli A: Altered response to rTMS in patients with Alzheimer's disease. Clin Neurophysiol 2006;117:103-109.

-59 Pierantozzi M, Panella M, Palmieri MG, Koch G, Giordano A, Marciani MG, Bernardi G, Stanzione P, Stefani A: Different TMS patterns of intracortical inhibition in early onset Alzheimer dementia and frontotemporal dementia. Clin Neurophysiol 2004;115: 2410-2418.

-60 Di Lazzaro V, Pilato F, Dileone M, Saturno E, Profice P, Marra C, Daniele A, Ranieri F, Quaranta D, Gainotti G, Tonali PA: Functional evaluation of cerebral cortex in dementia with Lewy bodies. Neuroimage 2007; 37:422-429.

-61 Ziemann U, Lonnecker S, Steinhoff BJ: Effects of antiepileptics drugs on motor cortex excitability in humans: a transcranial magnetic stimulation study. Ann Neurol 1996; 40:367-378

62 Chen R, Lozano AM, Ashby P: Mechanism of the silent period following transcranial magnetic stimulation: evidence from epidural recordings. Exp Brain Res 1999;128:539542.

-63 Kujirai T, Caramia MD, Rothwell JC, Day BL, Thompson PD, Ferbert A, Wroe S, Asselman P, Marsden CD: Corticocortical inhibition in human motor cortex. J Physiol 1993; 471:501-519.

64 Di Lazzaro V, Oliviero A, Meglio M, Cioni B, Tamburrini G, Tonali P, Rothwell JC: Direct demonstration of the effect of lorazepam on the excitability of the human motor cortex. Clin Neurophysiol 2000;111:794-799.

-65 Ziemann U, Chen R, Cohen LG, Hallett M: Dextromethorphan decreases the excitability of the human motor cortex. Neurology 1998;51:1320-1324

-66 Di Lazzaro V, Pilato F, Oliviero A, Dileone M, Saturno E, Mazzone P, Insola A, Profice P, Ranieri F, Capone F, Tonali PA, Rothwell JC: Origin of facilitation of motor-evoked potentials after paired magnetic stimulation: direct recording of epidural activity in conscious humans. J Neurophysiol 2006;96: 1765-1771.
67 Tokimura H, Di Lazzaro V, Tokimura Y, Oliviero A, Profice $\mathrm{P}$, Insola $\mathrm{A}$, Mazzone $\mathrm{P}$, Tonali P, Rothwell JC: Short latency inhibition of human hand motor cortex by somatosensory input from the hand. J Physiol 2000;523: 503-513.

68 Di Lazzaro V, Oliviero A, Profice P, Pennisi MA, Di Giovanni S, Zito G, Tonali P, Rothwell JC: Muscarinic receptor blockade has differential effects on the excitability of intracortical circuits in the human motor cortex. Exp Brain Res 2000;135:455-461.

69 Di Lazzaro V, Oliviero A, Saturno E, Dileone M, Pilato F, Nardone R, Ranieri F, Musumeci G, Fiorilla T, Tonali P: Effects of lorazepam on short latency afferent inhibition and short latency intracortical inhibition in humans. J Physiol 2005;564:661-668.

70 Chibbaro G, Daniele M, Alagona G, Di Pasquale C, Cannavò M, Rapisarda V, Bella R, Pennisi G: Repetitive transcranial magnetic stimulation in schizophrenic patients reporting auditory hallucinations. Neurosci Lett 2005;383:54-57.

71 Schönfeldt-Lecuona C, Lefaucheur JP, Cardenas-Morales L, Wolf RC, Kammer T, Herwig U: The value of neuronavigated rTMS for the treatment of depression. Neurophysiol Clin 2010;40:37-43.

72 Ziemann U, Hallett M, Cohen LG: Mechanisms of deafferentation-induced plasticity in human motor cortex. J Neurosci 1998;18: 7000-7007.

73 Alagona G, Ferri R, Pennisi G, Carnemolla A, Maci T, Domina E, de Noordhout AM, Bella R: Motor cortex excitability in Alzheimer's disease and in subcortical ischemic vascular dementia. Neurosci Lett 2004;362: 95-98.

74 Erkinjuntti T: Diagnosis and management of vascular cognitive impairment and dementia. J Neural Transm Suppl 2002;63:91-109.

75 Rossini PM, Barker AT, Berardelli A, Caramia MD, Caruso G, Cracco RQ, Dimitrijević MR, Hallett M, Katayama Y, Lücking CH, de Noordhout M, Marsden CD, Murray NMF Rothwell JC, Swash M, Tomberg C: Non-invasive electrical and magnetic stimulation of the brain, spinal cord and roots: basic principles and procedures for routine clinical application - Report of an IFCN committee. Electroencephalogr Clin Neurophysiol 1994; 91:79-92.

76 Kalaria RN: Comparison between Alzheimer's disease and vascular dementia: implications for treatment. Neurol Res 2003;25: 661-664.

77 Won SJ, Kim DY, Gwag BJ: Cellular and molecular pathways of ischemic neuronal death. J Biochem Mol Biol 2002;35:67-86.

78 Riedel G, Platt B, Micheau J: Glutamate receptor function in learning and memory. Behav Brain Res 2003;140:1-47.

79 Szydlowska K, Tymianski M: Calcium, ischemia and excitotoxicity. Cell Calcium 2010; $47: 122-129$.
80 Choi DW: Ischemia-induced neuronal apoptosis. Curr Opin Neurobiol 1996;6:667-672.

81 Román GC, Kalaria RN: Vascular determinants of cholinergic deficits in Alzheimer disease and vascular dementia. Neurobiol Aging 2006;27:1769-1785.

82 Di Lazzaro V, Pilato F, Dileone M, Profice P, Marra C, Ranieri F, Quaranta D, Gainotti G, Tonali PA: In vivo functional evaluation of central cholinergic circuits in vascular dementia. Clin Neurophysiol 2008;119:24942500.

83 Nardone R, Bergmann J, Tezzon F, Ladurner G, Golaszewski S: Cholinergic dysfunction in subcortical ischaemic vascular dementia: a transcranial magnetic stimulation study. J Neural Transm 2008;115:737-743.

-84 Manganelli F, Ragno M, Cacchiò G, Iodice V, Trojano L, Silvaggio F, Scarcella M, Grazioli M, Santoro L, Perretti A: Motor cortex cholinergic dysfunction in CADASIL: a transcranial magnetic demonstration. Clin Neurophysiol 2008;119:351-355.

85 Pennisi G, Ferri R, Alagona G, Pennisi M, Malaguarnera G, Motta M, Bella R: Motor cortex hyperexcitability in subcortical ischemic vascular dementia. Arch Gerontol Geriatr 2010. doi:10.1016/j.archger.2010.07. 004

-86 Delvaux V, Alagona G, Gérard P, De Pasqua V, Pennisi G, de Noordhout AM: Post-stroke reorganization of hand motor area: a 1-year prospective follow-up with focal transcranial magnetic stimulation. Clin Neurophysiol 2003;114:1217-1225.

87 Schmidt R, Ropele S, Ferro J, Madureira S, Verdelho A, Petrovic K, Gouw A, van der Flier WM, Enzinger C, Pantoni L, Inzitari D, Erkinjuntti T, Scheltens P, Wahlund LO, Waldemar G, Rostrup E, Wallin A, Barkhof F, Fazekas F; LADIS study group: Diffusionweighted imaging and cognition in the leukoariosis and disability in the elderly study. Stroke 2010;41:e402-e408.

88 Ragno M, Tournier-Lasserve E, Fiori MG, Manca A, Patrosso MC, Ferlini A, Sirocchi G, Trojano L, Chabriat H, Salvi F: An Italian kindred with cerebral autosomal dominant arteriopathy with subcortical infarcts and leukoencephalopathy (CADASIL). Ann Neurol 1995;38:231-236.

89 O'Sullivan M, Jarosz JM, Martin RJ, Deasy N, Powell JF, Markus HS: MRI hyperintensities of the temporal lobe and external capsule in patients with CADASIL. Neurology 2001; 56:628-634.

90 Everitt BJ, Robbins TW: Central cholinergic systems and cognition. Annu Rev Psychol 1997;48:649-684.

-91 De Carvalho M, de Mendonça A, Miranda PC, Garcia C, Luís ML: Magnetic stimulation in Alzheimer's disease. J Neurol 1997; 244:304-307. 
-92 Inghilleri M, Conte A, Frasca V, Scaldaferri N, Gilio F, Santini M, Fabbrini G, Prencipe M, Berardelli A: Altered response to rTMS in patients with Alzheimer's disease. Clin Neurophysiol 2006;117:103-109.

$\checkmark 93$ Julkunen P, Jauhiainen AM, Westerén-Punnonen S, Pirinen E, Soininen H, Könönen M, Pääkkönen A, Määttä S, Karhu J: Navigated TMS combined with EEG in mild cognitive impairment and Alzheimer's disease: a pilot study. J Neurosci Methods 2008;172:270276.

94 Liepert J, Bär KJ, Meske U, Weiller C: Motor cortex disinhibition in Alzheimer's disease. Clin Neurophysiol 2001;112:1436-1441.

95 Martorana A, Stefani A, Palmieri MG, Esposito Z, Bernardi G, Sancesario G, Pierantozzi M: L-dopa modulates motor cortex excitability in Alzheimer's disease patients. J Neural Transm 2008;115:1313-1319.

-96 Pepin JL, Bogacz D, de Pasqua V, Delwaide PJ: Motor cortex inhibition is not impaired in patients with Alzheimer's disease: evidence from paired transcranial magnetic stimulation. J Neurol Sci 1999;170:119-123.

-97 Di Lazzaro V, Oliviero A, Pilato F, Saturno E, Dileone M, Marra C, Ghirlanda S, Ranieri F, Gainotti G, Tonali P: Neurophysiological predictors of long-term response to $\mathrm{AChE}$ inhibitors in AD patients. J Neurol Neurosurg Psychiatry 2005;76:1064-1069.

-98 Di Lazzaro V, Pilato F, Dileone M, Saturno E, Oliviero A, Marra C, Daniele A, Ranieri F, Gainotti G, Tonali PA: In vivo cholinergic circuit evaluation in frontotemporal and Alzheimer dementias. Neurology 2006;66: 1111-1113.

-99 Bütefisch CM, Netz J, Wessling M, Seitz RJ, Hömberg V: Remote changes in cortical excitability after stroke. Brain 2003;126:470481.
100 Ihara M, Tomimoto H, Ishizu K, Mukai T, Yoshida H, Sawamoto N, Inoue M, Doi T, Hashikawa K, Konishi J, Shibasaki H, Fukuyama H: Decrease in cortical benzodiazepine receptors in symptomatic patients with leukoaraiosis: a positron emission tomography study. Stroke 2004;35:942-947.

101 Orth M, Rothwell JC: The cortical silent period: intrinsic variability and relation to the waveform of the transcranial magnetic stimulation pulse. Clin Neurophysiol 2004; 115:1076-1082

102 Rossini PM, Rossi S, Babiloni C, Polich J: Clinical neurophysiology of aging brain: from normal aging to neurodegeneration. Prog Neurobiol 2007;83:375-400.

103 Oliviero A, Profice P, Tonali PA, Pilato F, Saturno E, Dileone M, Ranieri F, Di Lazzaro V: Effects of aging on motor cortex excitability. Neurosci Res 2006;55:74-77.

104 Rossini PM, Desiato MT, Caramia MD: Age-related changes of motor evoked potentials in healthy humans: non-invasive evaluation of central and peripheral motor tracts excitability and conductivity. Brain Res 1992;593:14-19.

105 Silbert LC, Nelson C, Holman S, Eaton R, Oken BS, Lou JS, Kaye JA: Cortical excitability and age-related volumetric MRI changes. Clin Neurophysiol 2006;117: 1029-1036.

106 Peinemann A, Lehner C, Conrad B, Siebner HR: Age-related decrease in paired-pulse intracortical inhibition in the human primary motor cortex. Neurosci Lett 2001;313: 33-36.

107 Ferreri F, Pauri F, Pasqualetti P, Fini R, Dal Forno G, Rossini PM: Motor cortex excitability in Alzheimer's disease: a transcranial magnetic stimulation study. Ann Neurol 2003;53:102-108.
108 Reddy H, De Stefano N, Mortilla M, Federico A, Matthews PM: Functional reorganization of motor cortex increases with greater axonal injury from CADASIL. Stroke 2002;33:502-508.

109 Rektorova I, Megova S, Bares M, Rektor I: Cognitive functioning after repetitive transcranial magnetic stimulation in patients with cerebrovascular disease without dementia: a pilot study of seven patients. J Neurol Sci 2005;229-230:157-161.

110 Fabre I, Galinowski A, Oppenheim C, Gallarda T, Meder JF, De Montigny C, Olié JP, Poirier MF: Antidepressant efficacy and cognitive effects of repetitive transcranial magnetic stimulation in vascular depression: an open trial. Int J Geriatr Psychiatry 2004; 19:833-842.

111 Jorge RE, Moser DJ, Acion L, Robinson RG: Treatment of vascular depression using repetitive transcranial magnetic stimulation. Arch Gen Psychiatry 2008;65:268-276.

112 Bella R, Pennisi G, Cantone M, Palermo F, Pennisi M, Lanza G, Zappia M, Paolucci S: Clinical presentation and outcome of geriatric depression in subcortical ischemic vascular disease. Gerontology 2010;56: 298-302.

113 Wang F, Geng X, Tao HY, Cheng Y: The restoration after repetitive transcranial magnetic stimulation treatment on cognitive ability of vascular dementia rats and its impacts on synaptic plasticity in hippocampal CA1 area. J Mol Neurosci 2010;41:145-155.

114 Sakuma K, Murakami T, Nakashima K: Short latency afferent inhibition is not impaired in mild cognitive impairment. Clin Neurophysiol 2007;118:1460-1463.

115 Olazarán J, Prieto J, Cruz I, Esteban A: Cortical excitability in very mild Alzheimer's disease: a long-term follow-up study. J Neurol 2010; doi: 10.1007/s00415-010-5663-8. 